\title{
ON THE TRAIL OF JOHN CALVIN'S PHILOSO- PHY OF LANGUAGE: A FEW NOTES ON HIS COMMENTARY ON GENESIS 10 AND 11
}

\author{
${ }^{\dagger}$ N.T. van der Merwe ${ }^{1}$
}

\begin{abstract}
This essay attempts to discover John Calvin's view on the nature and use of human language. It suggests a strategy for establishing a few building blocks of his philosophy of language. For this purpose Calvin's Commentary on Genesis is analysed and commented on. Seven items to be incorporated in the structure are found to be important but inadequate. As a follow-up the author refers to the contemporary paradigm shift of linking the philosophy of language to contextual studies, pragmatics, rhetoric, ethics and hermeneutics.
\end{abstract}

\section{A PERSONAL NOTE}

Whenever I have the privilege of exchanging a few words with my close friend of many years, Ludi Schulze, I am struck, time and again, by his wideranging knowledge of theology, philosophy, the arts and music - a person who can handle a wide-angle lens with as much finesse as an intellectual microscope. While contemplating, accordingly, what kind of brick would best suit the structure of a Festschrift for this gifted, soft-spoken scholar, an analogy struck my mind. Some years ago I had the opportunity of suggesting a few building blocks of John Calvin's philosophy of language at the $6^{\text {th }}$ South African Congress for Calvin Research (August 2000, Potchefstroom).

1 Prof. N.T. van der Merwe, $\dagger$ September 14 $4^{\text {th }}, 2004$. Professor emeritus of philosophy, Potchefstroom University for Christian Higher Education. Prof Van der Merwe was in hospital while working on this contribution and although he died before he could conclude by adding his final finishing touches, the editors came to the conclusion that it would not only be worthwhile but indeed an enrichment for the Festschrift to publish this remarkable piece of research. As co-editor of this Festschrift I want to convey my sincere gratitude to Mrs. Heléne van der Merwe, widow of the late prof. Theo van der Merwe, as well as to their son, dr. Theodor van der Merwe, who were very kind and helpful after his death to give me access to the latest files on his computer for reconstructing the final version of this article - VE d'A. We also appreciate the trouble Mrs Irene Stotko, their daughter, took to edit and proof-read a significant part of the article. 
Maybe the fascination with language as a cultural phenomenon, which I share with professor Schulze, could serve as mortar for illustrating our intellectual affinity.

\section{INTRODUCTION}

The theme of the Congress was "John Calvin as minister of the Word". A theological perspective on language - focusing on Calvin — would certainly have been appropriate, treating topics such as religious language, sacred texts, biblical stories, parables and figurative speech, the nature and scope of revelation, word and Word, and so forth. The decisive question was whether Calvin's literary heritage also requires a philosophical investigation, a basic general study of his conception, use and evaluation of language.

Testing this route of research involved, however, a shock experience of extreme vehemence: none of the major contemporary philosophical encyclopaedias or dictionaries seems to have travelled to Geneva. Calvin himself, on the other hand, does not seem to have planned a treatise that would articulate his view of language. And, surprisingly, a search for relevant titles in, for example, Peter de Klerk's careful and precise yearly overview of Calvin literature in the Calvin Theological Journal proved to my amazement nearly fruitless. But could this really be the case?

If a worldly directive reculer pour mieux sauter may have any practical significance - and if I may permit myself a little intertextual fun?! - I hope that we will hit firm soil well outside the scope and preconceptions of both absolutist modernism and relativising post-modernism, all the while treasuring Calvin's maxim facilitas et brevitas close to our hearts for this inquiry. And finally, let us pursue our goal of tracing some building blocks by designing an adventurous treasure bunt for this purpose, while at the same time bearing in mind that the intersection of and the grey area between a philosophy and a theology of language reveal its own meaning horizons but transcend the scope of our present focus.

\section{CONTEXTUALISING A SEARCH FOR CALVIN'S PHILOSOPHY OF LANGUAGE}

\subsection{Calvin's passion}

Calvin unfortunately did not write an essay on language. But he was a prolific writer, even though he distanced himself from the prolixity of several of his contemporaries, both Humanist and Reformed — and indeed prolific 
in many literary genres as well. Calvin lived coram Deo in his commentaries on the Bible, his sermons, his lectures and erudite disputations, his polemical tracts, letters, and even an extant poem as well as a rhymed version of a few Psalms. Which of these shall one prioritise in order to glean some insights into Calvin's use of and opinion on language?

As the search was at that stage on for "Calvin as minister of the Word", an obvious entrance would have been to join the crowd listening to one of his penetrating sermons or step into his study and watch him commenting on one book of the Bible after another in his own favourite procedure of exegetica continua - with meticulous attention to the essence and details of the material on hand. If one should choose the latter option, the problem remains which commentary one should choose in order to focus on language.

The Bible presents several marvellous beacons, which witness to the function of language, such as God creating the universe by the power of his Word, naming items of creation and conversing with humankind, even renaming persons and eventually confusing the builders of a mighty city; the 'grandparents' of humanity, naming, speaking and responding to God; or God's lingual commandments on durable tablets; a snake talking to Eve, and Bileam surprising us with a donkey talking lingual sense; a writing on the wall in a royal court; a choir of angels praising God; the seven last words of Jesus and the cross on Golgotha charging the divine Saviour of the world in the prominent languages used in Palestine at that time; a miraculous adaptation to a variety of vernacular languages, close-circuiting a translation crisis; letters from heaven to various churches, and much more. It is clear that 'synthesising' a 'harmony' of the materials would be out of the question within the bounds of this fragment and would need a more encompassing investigation. I shall accordingly zoom in on the incisive origin of a plurality of languages on earth, mentioned in Genesis 10 and 11. My reasons will become clearer in due course.

\subsection{Calvin on the unity and diversity of human language}

Calvin's In primum Mosis librum, qui Genesis vulgo dicitur, Commentarius Johannis Calvini was published in Geneva by Robertus Stephanus in $1554 .^{2}$ In chap-

2 Edition in $\mathrm{CO} 23$.

$\mathrm{CO}=$ Calvini Opera Omnia, i.e., Ioannis Calvini Opera Quae Supersunt Omnia, Vol. I-LIX. 1863-1900. Ediderunt G[W]. Baum, E. Cunitz \& E. Reuss, Vol ILIX, in Corpus Reformatorum, Vol. XXIX-LXXXVII. Brunsvigae/Berolini:

C.A. Schwetschke et filium. [ = CO 1-59.] 
ters 10 and $11^{3}$ the language issue is coupled with the genealogy of early humankind and we shall have to deal with it in this intermingled fashion. Is it perhaps part of the 'confusion' of Babel?

I shall now digest a few important facets in chapters 10 and 11 by means of a (selective) interpretive analysis. By paraphrasing or translating Calvin's thought in a free style, I nevertheless try to remain in the 'atmosphere' of Calvin. Please bear in mind that I intend to follow Calvin on the trail of his comments, zooming in on the language issue, and bracketing all or most other topics - not as trivial but as not necessarily relevant. I accordingly also do not discuss a question such as the authenticity of Moses as author of Genesis.

\subsubsection{Calvin surprises us with an initial declaration of his stance as a scholar}

I don't mind, Calvin declares, the industrious efforts of someone investigating rather in detail the genealogies presented by Moses (diligentiam non improbo). ${ }^{4}$ As a matter of fact, some interpreters have devoted their energies and scholarly attention to this endeavour with quite splendid results (non infeliciter). ${ }^{5}$ Let them enjoy the prize of their labours! But guard against vain curiosity (frivola curiositas). ${ }^{6}$ The choice of words and phrasing is evidence of Calvin's critical but moderate view of intellectual labour and his aversion to fanaticism and waste of precious time on trivialities.

As far as I am concerned, Calvin continues, it suffices to treat briefly what in my opinion is more useful (magis utilia censeo) and why these lists (catalogi) had been written by Moses. In the first place those bare names do represent a fragment, but only a part of the history of the world, namely the time that has elapsed from the great Flood to the covenant with Abraham. This second commencement (origo) of the human race is especially noteworthy because the ingratitude of those who have actually heard from their forefathers the miraculous renewal of the world in such a short time-span is detestable for having forgotten God's grace and preservation. This impious

Cf. Peter R. \& Gilmont, J.-F. 1991. Bibliotheca Calviniana. Les œuvres de Jean Calvin publiées au XVIe siècle, I. Écrits théologiques, littéraires et juridiques 1532-1554. Genève: Libraire Droz. (Travaux d'Humanisme et Renaissance, CCLV.) p. 519-523.

3 CO 23, 156-172.

4 CO 23,157.

5 Ibid.

6 CO 23,158. 
oblivion by the majority has opened a door to the lies of Satan, distorting real history with the fables of the poets of antiquity. ${ }^{7}$

Calvin thus clearly has a fine sense of the linguistic implications of not merely local history, but indeed of world history as 'written' by Moses, as well as a critical insight into the oral tradition ('what' has been remembered or forgotten). Calvin indeed takes a much more moderate stand towards genealogical interest than the apostle Paul had expressed on account of his encounters with Jewish fervour on special lines of descent. But Calvin is adamant that these lists of names present only a fragment of history and that attention can rather be devoted to more useful issues. What Calvin has in mind with these utilia is a rather complex issue to decipher, and has in part to be discovered from his life as an example. It is complex because Calvin does consider attention to the genealogy of the human race important in so far as it is part of the earliest history of humankind as 'reported by Moses'. This history should be kept alive in memory because it impresses on us the grace and patience of God with humankind, initiating twice a new start for the human race.

\subsubsection{The narrative of Genesis 10 now continues with a second} start

Calvin comments on a second renewal of humanity and an abominable oblivion of God's gracious intervention with the first, which gave Satan an opportunity to instigate the fictive fables of the poets (note the close link between fabula and mendacia), falsifying the truth of God's work. What a discrepancy between God's goodness and man's atrocities that the lives of ungrateful, wild and uncivilised foreigners (barbari - those not conversant in one's own language) would be prolonged! Even men who do not acknowledge a creator of the world laugh at such a quick propagation, considering it an imaginative story. But here one should be attentive to the considerate intention of the Holy Spirit, willing the earth to be populated far and wide. ${ }^{8}$

I would now like to comment as follows on Calvin's interpretation: Calvin differentiates sharply between good and bad, between the goodness and mercy of God and (with only a few exceptions) the ungrateful response of man after having been given a second lease of life. In this connection the lingual hinge with the past (remembrance and oblivion) is especially noteworthy. Secondly, Calvin draws Satan into the picture even where Moses does not

7 CO 23,157.

8 Ibid. 
necessitate him doing so textually, and emphasises the close lingual link between the destructive influence of Satan and the invalidation of the real ethical function of language (speaking the truth).

\subsubsection{The Holy Spirit}

The mention of the Holy Spirit constitutes a third important link in Calvin's interpretative comments: The mystery of creation includes the involvement of the Holy Spirit in the development of history, even explaining a miraculous renewal on earth. Calvin extends the relevance of the Holy Spirit to humanity by referring to Noah's admiration in witnessing these events with his own eyes, honouring God and marvelling at his majestic power, celebrating his goodness and acknowledging his hand in history thus relating the secret acts of God not only to the creation of the world but also to its renewal.

At that time those with earthly aspirations excelled, but their glory evaporated soon. In the mean time the church survived in an appalling state until it could raise up in its own proper time. The words chosen by Calvin is again revealing of his sound doctrinal and historical sense. Once again Calvin is sober-minded and matter-of-fact about gaps or defects in the Bible narrative: it stands to reason that some links in the three-pronged narrative of Moses would have been lesser known to the Jews (for example on account of distant regions).

\subsubsection{Genealogy}

Genealogy deals with names thought to be representative of a specific lineage. But names as such are not indicative of the Spirit's impact on human history and bare names are not to be taken as representative of certain and distinct groups of people inherent in each specific name - a sign of trifling curiosity according to Calvin! Although thus acknowledging the importance of names and ethnic groups, Calvin denounces firmly a speculative or mystical tracing of origins by means of linguistic techniques. The role of the Spirit is of prime importance here - right through history.

At that time outstanding persons such as Noah took the lead with such moderation that equality with their minors could be cultivated so that they could be honoured spontaneously rather than by coercion or demand. Whoever is mindful of the status of man, cherishes the close bond between human beings. However, forgetting that he is merely a human being, Nimrod usurped a higher level for himself. His ambition threw into confusion and shattered the limits of an unassuming moderate conduct. A metaphorical understand- 
ing of Nimrod's name supports the proverbial interpretation of Jerome, comparing a courageous but violent person to a Nimrod. Here it thus becomes clear that a moderate arrangement of affairs is pleasing to God (Deo placet moderata administratio inter bomines). ${ }^{9}$

It seems to me that Calvin practised this socio-political maxim also in his attitude towards and use of language; moreover, he could evaluate with sound criticism the pros and cons of a proper and figurative (metaphorical) meaning of words.

\subsubsection{The name Babel}

As far as the city called Babel is concerned, Calvin doubts the amplitude and magnificence of its structure according to worldly writers. Regarding the name of this city - meaning 'confusion' - Calvin mentions one interpretation explaining the dilemma (namely that the city's name already had its meaning before the erection of the splendid tower) as the rhetorical procedure of bysteron prooteron, i.e. Moses narrates an incident as previous in the order of time. ${ }^{10}$ As an interpretive tool Calvin himself prefers a prolepsis, i.e. a conjecture that Moses bestowed this name on the city on account of a new factual event. The sense of this conjecture is that it is probable that those places were already well populated with people who could tackle the immense mass of work. Calvin also considers it possible that Nimrod was anxious about his fame and power, and therefore kindled their foolish passionate desire with this pretext that an illustrious monument will be constructed wherein their eternal memory would be conspicuous. ${ }^{11}$ Calvin here shows his prowess in dealing with rhetorical figures linked to the use of language.

As far as the rest of chapter 10 is concerned, suffice it to say that Calvin once again manifested his philological erudition by attributing an old proverb to Nimrod's ferocious personality, namely "a formidable reign involves major robberies". ${ }^{12}$ Calvin is also sensitive regarding the social aspect of humanity: God initiated a renewal of a close bond between the brothers Sem and Japheth, notwithstanding all the calamities caused by $\sin .^{13}$

$9 \mathrm{CO} 23,159$.

10 CO 23,160.

11 Ibid.

12 CO 23,160: “... unde prodiit vetus proverbium, Magna regna esse magna latrocinia."

$13 \mathrm{CO} 23,160 \mathrm{f}$. 


\subsubsection{The media sententia}

Especially the first part of chapter 11 is relevant to our theme.

Calvin explains that previous mention was made of Babylon, but only briefly, and that Moses now elaborates on important facets of this history, which shows how stubbornly people can oppose the will of God. Calvin draws attention to the fact that the words of Moses do not substantiate a certain interpretation, which explains the inducement for building the tower (as a haven) as a precautionary measure against a probable drowning of impious people by God's judgment. In actual fact, Moses reveals this monstrous mad ambition and haughty disdain of God to be the intended plan and objective of the building project whereby they expected to obtain an immortal name on earth. An overrating of human self-esteem implies contempt of and conflict with God. ${ }^{14}$ We discover here, I think, a fine-tuning to the ethical problem of self-esteem (the value of one's name, in this instance a haughty self-deception) linked to a political aspiration of glory in the polity.

According to Calvin the fable of the gigantes (giants) and the time calculation of Berosus have little factual substance. He is of the opinion that Moses effectively crumbles the vain contradictions, which impious people find in the books of Moses. ${ }^{15}$ As far as the time calculation concerning the differentiation (in a literal sense separation) and confusion of languages are concerned (linguarum confusio), we (i.e. Calvin, and in a general sense the Bible expositor) are free to follow a middle route (mediam sententiam tenere licebit) ${ }^{16}$ - a rather important hermeneutical directive, which Calvin discloses in this context. Moses' reference to one initial speech system (language) on earth (terram fuisse labii unus) praises God's exceptional grace in maintaining the sacred social bond whereby these people could use one common language (ut communem baberent inter se linguam), even though persons were internally displaced. ${ }^{17}$

I think it would be fair to say that Calvin used a comparative method to his advantage, highlighting God's grace in history.

$14 \mathrm{CO} 23,162 \mathrm{f}$.

15 CO 23,163.

16 Ibid.

17 CO 23,164. 


\subsubsection{The diversity of languages}

Let us pursue Calvin's comments on this section of chapter 11 in more detail. The diversity of languages must indeed be considered a prophetic sign. As language is the (external) mark of the mind (mentis character lingua esse), ${ }^{18}$ how is it possible, Calvin contends, that human beings — sharing the same reason and being born for a social life — are unable to communicate in language? This must surely be a defect as it is in conflict with nature. A divine punishment was indeed inflicted on people to disperse their languages for conspiring against God. Unity of language (linguae unitas) should on the contrary have inspired them towards a pious concord. But this mob united in declaring war on God after having alienated themselves from the pure adoration of God and the holy communion of the faithful. God's punishments accordingly quite rightly divided their languages. It is clear that not only Nimrod, but also all conspired together, and everyone incited the other in taking risks, because the desire for glory obsessed them to make a name for themselves. Even death does not correct this vain pride to attack heaven itself like giants. But notwithstanding human pride God's benevolence allows nations in spite of different languages to communicate with one another. ${ }^{19}$

In chapter 11 Calvin presents a 'peephole' into his conception of language, which is of great importance in so far as it shows the close relationship between a philosophy of language and his anthropology. It is remarkable that Calvin did not consider a differentiation as far as reason is concerned — with some people having bad, even malicious, ideas and others pious ideas. It is a pity that Calvin did not here elaborate on his view of language and left the puzzle unsolved, as in Latin the word character can have three meanings: (a) an instrument for branding or marking; (b) the mark or sign burned or imprinted; and (c) a characteristic, mark, character or style. What choice should we make? In order to pinpoint his conception of the relation of intellect and language (word and speech) we are accordingly obliged to initiate a further search elsewhere in his commentaries, in other writings, and of course especially in the Institutes, where Calvin considered in more detail and maturity many intricate problems and ideas on a variety of issues.

18 Ibid.

19 Ibid. 


\section{ANY BUILDING BLOCKS IN THE BRICKS OF BABEL?}

\subsection{Some implications of the search for contextualising Calvin's comments on Genesis 10 and 11}

We must now address the issue of evaluating our findings about Calvin's comments on these chapters. We have found that Calvin addressed many issues related to the nature, role and function of language in these chapters - some facets in more detail, others more superficially. Before we attempt a tentative synopsis of the results obtained, we should first consider whether the choice of focusing on chapters 10 and 11 was sensible and relevant.

Because of space limitations it is not possible to treat this question properly in this context. I can merely report that an investigation of the rest of Calvin's Commentary on Genesis (a) corroborated the advantage of this choice and (b) indicated that the remaining chapters do contain some important additional material, which is relevant for evaluating Calvin's conception of language. The initial chapters of Genesis, for example, deal with speaking and naming in a most fascinating way. Additional insights from Calvin's comments on these topics - and others - are essential for obtaining a full and balanced picture of what philosophy of language can expect from Calvin.

As a very incomplete illustration of what this would entail, let me mention one example only. The idea of confusion is basic to what happened to the unity of language in chapter 11. A conceptual analysis indicates some differences as far as Calvin's contextualising of the term confusio is concerned. In most instances it has a clear negative connotation, sometimes stronger and sometimes weaker. A few examples may suffice. Consider phrases such as Satan knew confusion would be produced; dreadful confusion (in our life); great confusion and disorder; terrible confusion; confused mass; confused emptiness; confused admixture; confused sense of evil; confused sound; cast Cain in confusion to the ground; confusion of tongues; speak confusedly; confused mind; lawless confusion; fly in confused and erratic circles.

To return now to my argument concerning a full picture of Calvin's conception of language, the Opera omnia contained only sermons on later sections of Genesis. With the recent very competent critical edition of the previously unpublished (French) sermons on Genesis Sermons sur la Genèse by Max 
Engammare ${ }^{20}$ it is now possible to test one's findings within this genre by means of a comparative method. An initial sample - especially on the earlier sections of Genesis - seems promising, but cannot be treated in this context. I have to limit myself to a brief recapitulation of the relative significance of my findings regarding the topic of unity and diversity of language obtained above.

The point of contact between Calvin's comments on various 'topics' and specifically that of language - reveals an erudite use of language, a thorough knowledge of the intellectual tools of the trade of a 'running commentary', an individual and critical mind with a talent for focusing on essential issues - tempered by a deep sense of the significance of moderation and, sometimes, the necessity of a via media. It seems, however, premature to distil Calvin's philosophy of language from the limited scope of my seven clusters of findings sketched above, as it cannot at this stage be considered full-fledged and proper building blocks of Calvin's philosophy of language. It warrants only the following conclusion: (1) Calvin has a clear sense of what language is about in so far as its use is concerned. (2) From Calvin's use of language one can recover some essential items to help in one's search for his conception of language proper, e.g. his attitude towards a proper meaning of words and a figurative meaning of words that cover, for example, instances of analogy, metaphor and allegory. (3) His conception of language is closely linked to inter alia his anthropology; to his view of knowledge, intellectual culture, method and interpretation; to his view of human culture and its effects on issues of faith; and to his basic ontology, dealing with creation as such, including the problem of good and bad (evil), but also the relation of language (word) and reality. These facets are interrelated and cannot be dealt with effectively in isolation. (4) It is therefore legitimate to ask which of the various philosophies of language would be appropriate to assist us in discovering and putting together the (real) building blocks of Calvin's philosophy of language, and also assist us in determining the relation between a philosophy and a theology of language that can account for Calvin's overall dealing with language. This important question, however, cannot be answered in a short article.

If the findings thus far on the basis of a section of the Genesis Commentary cannot all be considered proper building blocks, but perhaps only parts of bricks, mortar and plaster filling up gaps, is there not perhaps already a

20 Calvin, J. 2000. Sermons sur le Genese Chapitres 1,1-11,4 E 11,5-20,7. Ed., Engammare, M. In Supplementa Calviniana, Sermons inédits: Vol. XI/1, XI/2. Neukirchen-Vluyn: Neukirchener Verlag. 
proper framework available, which we have missed thus far? Was the disappointment with the results obtained with the help of the bibliographies of the Calvin Theological Journal really a cul de sac? To attempt to answer this question, I have to continue my contextualising a bit further where it had to be left earlier and ask what happened after Babel.

\subsection{The language issue during the time of the Reformation}

Let us now consider what position language had in the time of the Reformation. To summarise very sketchily: the Renaissance displayed an enthusiasm for (facets of) the classics, which stimulated an interest in art, literature, and languages relevant to that literature - far beyond the scope and limits of mediaeval ecclesiastical literature. It was a time in which interest in a variety of vernacular languages flourished. The universal genius Leonardo da Vinci marvelled at the unlimited potentialities of human creativity. In his wide-ranging Der Turmbau von Babel, ${ }^{21}$ Arno Borst pinpoints the language issue briefly, but with exquisite insight:

Leonardo gebrauchte seine lingua materna, ohne ortographische und grammatische Regeln zu beachten; er beklagte ihre Armut nicht, sondern fand in ihr alle Wörter, die er brauchte, um die Begriffe seines Geistes auszudrücken; er seufzte eher darüber, daß er die Dinge nicht richtig begriff. Die Sprachen sind unendlicher als der menschliche Geist; sie sind nicht das Geschöpf des Menschen. Sie spiegeln die Dinge, sie machen das Buch der Welt lesbar; aber sie sind auch keine Naturkraft. Kein metaphysischer Geist hat sie geschaffen, denn Sprache ist etwas Körperliches; der Geist hat keine artikulierte Stimme. Was also ist die Sprache? Leonardo gibt keine Antwort. ${ }^{22}$

Leonardo da Vinci still surprises us with his spurts into the future far beyond his age. But in the final analysis he had no answer. Do we, so-called 'post-modernists', today really have a proper answer concerning the mystery of language?

The impetus of Humanism, especially also Christian Humanism, cultivated scholars of great standing, among whom we find the philological erudition of the versatile Erasmus with a wide range of scholarly editions. It is worthwhile to consider carefully the summary by Borst of the real significance language had for Erasmus:

Erasmus lebte und wirkte in der Sprache; er wirkte in der Sprache; er schrieb ihr fast göttliche Ehren zu und verglich sie wie Anselm

21 Borst, A. 1960. Der Turmbau van Babel, III/1. Stuttgart: A. Hiersemann.

22 Borst 1960:1102. 
von Canterbury, zuversichtlicher als Nikolaus von Kues mit der göttlichen Dreifaltigkeit. Der mens, das Wort und der Geist wirken auch in der Sprache zusammen; sie macht den Menschen zum Ebenbilde Gottes. Sie trennt ihn vom Tier; der Mensch ist das Wesen, welches spricht und das Wort Gottes versteht. Zwischen Schöpfung und Schöpfer steht der Mensch, zwischen Begabung und Aufgabe. Sprache ist dem Menschen geschenkt, aber damit er die Wahrheit sage. Sie vermittelt ihm Sachwissen, und sie erzieht ihn zu seiner Klarheit und Schönheit. ${ }^{23}$

The Reformation could and did benefit from the two cultural movements mentioned above and the revolution of the printing industry as well. It was an epoch of great excitement! In so far as the Reformation is concerned, the influence of Luther's German Bible and Calvin's sustained efforts in shaping French as a respectable vehicle of communication and writing are well known and acknowledged as such. I need not dwell on this area in this context (the significance of translation and development of the vernacular). But there is another facet linked to the previous traits that I cannot ignore and will only be able to mention in a fragmented way.

In the Middle Ages Ecclesiastical Latin focused on the Church. A new interest in vernacular languages now initiated a formidable competition, which could stimulate development but at the same time had an inherent danger, as it was linked to nationalities and pride in one's own tongue as the best - because most original. Umberto Eco has sketched the theories and practices of these mighty historical tendencies in a brilliant synopsis with the title The search for the perfect language. ${ }^{24}$ I would have loved to comment on this fascinating study, but the context prohibits me from doing so. It is, however, relevant to mention in this context that it is really strange that not a single word concerning the contribution of Calvin is added to the myriad of voices. Why, o why, is Calvin ignored? Suffice it to say that Borst gives a plausible clue to unravel this intriguing question:

'Sprache' war ihm überhaupt nur ein Werkzeug, ein Mittel der Verständigung und vor allem der Verkündigung. Darum, und nicht aus Sprachstolz, predigte und schrieb der Reformator auch französisch und half so die französische Literatursprache mit durchsetzen. Wer sich auf die Seite Gottes stellte, mußte durch alle diese irdischen Verkörperungen hindurch auf die geistliche Lehre schauen. ${ }^{25}$

24 Eco, U. 1997. The search for the perfect language. London: Fontana.

25 Borst 1960:1131. 
It thus appears that Calvin did not travel on the beaten track like many of his contemporaries who theorised about the perfect language and considered their own as expression of their national identity and political aspirations. Aware of the present imperfection of creation Calvin did not fit in the long chain of writers who wrestled with the unity of Europe amidst a great variety of vernacular (and a few scholarly) languages. The special merit of Calvin is thus his absence in the row of learned intellectuals who gave all their energies to solve a serious intellectual problem, a problem that entails an intriguing but wrongly posed question. I would accordingly - Deo volente - like to have another look some time in the future at what and why Calvin did not tackle certain problems nor write certain treatises. Perhaps his philosophy of language might still in the future give us a few indications or at least some clues?

I may now close this section by asking once again whether the cul de sac, which I encountered right at the beginning, is real or perhaps a labyrinth in disguise? Did I perhaps initially miss an alternate route with relevant treasures? It seems to me that we are fortunate that — as far as the philosophy of language is concerned - we can rule out the first possibility and need now determine which alternate routes may be promising.

\section{EUREKA!?}

\subsection{A new strategy for observing language on planet earth}

While the adrenalin is still on a high after the excitement of the treasure hunt, we may just as well implement a new strategy and survey the language phenomenon on planet Earth from a high vantage point, or even better on board a satellite spinning alongside the earth's atmosphere. Signals that have been received indicate that some natural languages are declining, even perishing, while there are still fans of some artificial languages. Especially computer languages are thriving, catering for the programming needs of millions. Phonology and semantics have entered a new phase, while data transfer and manipulation techniques have become part of the globalising trends of the information revolution. The information engine has spread its wings and become entangled in the competition girdle, and monopolies have become prime targets. Cognitive science wrestles with the problem in what sense and measure the human mind can be simulated; it is presently exploring the relation between thought and language, especially the vexing question of the 'brain machine' and the boundaries of artificial intelligence. Speech recognition has progressed tremendously. Talk as an active event has received a new 
electronic application in the business and security environments. Translation techniques have also benefited from technological advancements. General linguistics, especially phonology and semantics, but also pragmatics, discourse theory and rhetoric as well as the needs of scientific terminology have all been revamped. New trends such as Neuro linguistic programming have emerged with imaginative applications in practical life. Interpretation theory has developed at a steady pace and invaded many new areas. Electronic media now handle the text of the Bible and a new generation of dictionary design and outlay as well as term retrieval has emerged. Hackers, viruses and idea thieves have invaded the information world and new borders for corporate ethics had to be delineated. Global chat rooms have become available even to children. With paradise lost a large section of humankind does not seem to worry at all about alienation from God; it is now a question of alienation from our environment, workplace, parents and family, home and so forth. Immense technological potentialities challenge danger spots. All these developments have brought new challenges to the philosophy of language. The majority of studies focus, however, on facets of language or specific sections of linguistics and few elucidate or synthesise the multi-functional character of language as such.

Let us pause a moment and ask how Calvin would have perceived our situation. Perhaps this is not a fair question and not a fitting occasion either but it is important to look at how these changes, sometimes even paradigm shifts, may affect Calvin research and cause far-reaching adaptations and reevaluations of customary research. Seen from a satellite perspective one can glance important advances and shifts in scholarly interests. If one has a look at the debates and investigations of scholars, but also at the practices and procedures in the publishing world and increasingly on the Internet, one can notice radical changes during the past decade with regard to inter alia literature (what is a text/document?); language practice (pragmatics) and as a corollary an emphasis on dynamic action and the speaker event; communication and rhetoric; understanding, interpretation, exegesis, explication, and linguistic application. It is clear that knowledge, even definition, has become open-ended. A paradigm shift has occurred. One important outcome is that language has become an integral part of diverse contexts and has to be discovered in various situations, either in a direct or indirect setting. We still have to pursue the second option in order to discover how these trends impinge on Christianity and Calvin research in particular.

Let us try one avenue for a start. At the International Calvin Congress of 1990 at Grand Rapids, Michigan, Richard Gamble made an important remark, which is relevant to the present context. In his contribution "Cur- 
rent trends in Calvin research, 1982-1990"26 Gamble made the following comment in the section regarding 'Calvin, language, and hermeneutic': "It is in this third area of recent Calvin research that, in my opinion, some of the greatest advances have been made and that much more research is needed." ${ }^{27}$ Let us therefore investigate briefly how language is intertwined with hermeneutics.

\subsection{Rumblings in the area of hermeneutics}

In his illuminating study The two horizons: New Testament hermeneutics and philosophical description with special reference to Heidegger, Bultmann, Gadamer, and Wittgenstein ${ }^{28}$ A.C. Thiselton has described the philosophical foundations of some key contributions to hermeneutics during the past decades (with original insights into especially Wittgenstein's approach). A little more than a decade later Thiselton published a masterly overview of the development of hermeneutics in a variety of areas, which explain admirably a variety of new trends regarding the role of language to which we have alluded above. Here P. Ricoeur, J. Habermas, W. Iser, U. Eco and others find their niche as well.

As an illustration of a significant response to some of these trends, I would like to refer to one relevant example. In a most readable booklet $H$ as the Church misread the Bible? The history of interpretation in the light of current issues, M. Silva has delineated the current predicament of Christianity and investigated the 'hermeneutical crisis' in a sober and balanced way. ${ }^{29}$ This is a crisis that affects the essence of inter alia the nature of sacred texts, scriptural authority, inspiration, infallibility, inerrancy, the clear message of the Bible, author's intent, historical reconstruction, contextualisation and so forth. New ideas that have occurred about pre-understanding and pre-suppositions necessitate a new look at understanding and interpretation, the

26 Gamble, R.C. 1994. Current trends in Calvin research, 1980-1990. (In W.H. Neuser, Hrsg., Calvinus Sacrae Scripturae Professor: Calvin as confessor of Holy Scripture. The papers of the International Congress on Calvin Research, from August $20^{\text {th }}$ to $23^{\text {rd }} 1990$ in Grand Rapids. Grand Rapids, Michigan: William B. Eerdmans, pp. 91-112.)

27 Gamble 1994:102.

28 Thiselton, A.C. 1980. The two horizons: New Testament hermeneutics and philosophical description with special reference to Heidegger, Bultmann, Gadamer, and Wittgenstein. Grand Rapids, Mich.: Eerdmans and Exeter, Paternoster.

29 Silva, M. 1987. Has the Church misread the Bible? The history of interpretation in the light of current issues. Grand Rapids, Mich.: Zondervan/Academie Books. 
clarity or ambiguity of meaning - especially the long-standing isssue of a hidden meaning and a sensus plenior (cf. Paul Ricoeur's 'surplus of meaning').

Silva's thesis is that the history of Biblical interpretation has been characterised by the Church's appreciation of difficult tensions in one's reading of Scripture. ${ }^{30}$ His conclusion, which may perhaps not find universal assent, is remarkable: "The attempt to hold these seeming polarities in tension, is the principle that brings unity to the great diversity of problems surrounding the history of Biblical interpretation." ${ }^{31}$ On this basis Silva is adamant that "no paragraph in Christian documents need be excised on account of advances in textual criticism or philology" and concludes that "all of the increased knowledge and sophistication of the modern era does not suggest for a moment that previous generations of Christians have misunderstood the Gospel message". ${ }^{32}$

Perhaps we could add to this assessment the clue presented by H. G. Gruenler in his Meaning and understanding: the philosophical framework for Biblical interpretation: ${ }^{33}$ “... the bottom line of humanistic hermeneutics, whether ancient or modern, is the rejection of the sovereignty of God in the enterprise of meaning and understanding, and the substitution of the sovereignty of human thought..."34 It seems to me that this insight is applicable even to $20^{\text {th }}$ Century Irrationalistic trends and socalled Postmodern shifts - but in a much more complex way. To counteract the trend mentioned above, Gruenler advocates a kind of Anselmian approach, emphasising that the quest for wisdom, meaning and understanding is a legitimate and necessary pursuit. Christian philosophers should play a significant role in the interpretive process by providing important hermeneutical skills and insights in the use of logic, reasoning, analysis of presuppositions, ethics, aesthetics, and the weighing of world-views". ${ }^{35}$ (p.174). I should like to add the philosophy of language to this list.

Let us now focus on an application to Calvin.

30 Silva 1987:37.

31 Silva 1987:38.

32 Silva 1987:92.

33 Gruenler, H.G. 1991. Meaning and understanding: the philosophical framework for Biblical interpretation. Grand Rapids, Mich.: Zondervan.

34 Gruenler 1991:61.

35 Gruenler 1991:174. 


\subsection{The hermeneutics of Calvin}

Since 1990 relatively little had been published explicitly on Calvin's conception of language, but quite a few studies do touch on language indirectly. And quite a few are of exceptional quality! ${ }^{36}$ It must be noted, however, that a great majority of substantial contributions to Calvin's philosophy of language are veiled in the cloak of either rhetoric or hermeneutics. ${ }^{37}$ In these

36 Cf. contributions such as Olivier Millet's solid and erudite study Calvin et la dynamique de la parole: Etude de rhétorique réformée, 1992. Paris, Librairie Honoré Champion. (Bibliothèque Littéraire de la Renaissance, Série 3, Tome XXVIII.) This study has not only treated issues in the area of a theology of language like word/Word with exemplary erudition, but also contributed vastly to our understanding of various characteristics of language as such - and of course to our appreciation of the significance of Calvin.

Cf. also in this regard Millet, O. 1997. Docere/Movere: Les catégories rhétoriques et leurs sources humanistes dans la doctrine calvinienne de la foi. (In W.H. Neuser und B.G. Armstrong, Hrsg., Calvinus Sincerioris Religionis Vindex - Calvin as Protector of the Purer Religion: The papers of the International Congress on Calvin Research, from August $13^{\text {th }}$ to $16^{\text {th }} 1994$ in Edinburgh, Scotland, Vol. XXXVI of Sixteenth Century Essays and Studies, General Editors: C.G. Nauert, Jr., and R.A. Mentzer. Kirksville, Missouri: Sixteenth Century Journal Publishers. pp. 35-51.)

37 Cf. e.g. the special contributions of Ganoczy, A. \& Müller, K. 1981. Calvins handschriftliche Annotationen zu Chrysostomus: Ein Beitrag zur Hermeneutik Calvins. Wiesbaden: F. Steiner. (Veröffentlichungen des Instituts für Europäische Geschichte Mainz, Bd. 102, Abteilung für Abendländische Religions-ge-schichte, hegausgegeben von Peter Meinhold.) Ganoczy, A. \& Scheld, S. 1983. Die Hermeneutik Calvins: Geistesgeschichtliche Voraussetzungen und Grundzüge. Wiesbaden: F. Steiner. Torrance, T.F. 1988. The hermeneutics of John Calvin. Edinburgh: Scottish Academic Press. Schreiner, S.E. 1991. The Theater of his Glory: nature and natural order in the thought of John Calvin. Durham, North Carolina: The Labyrinth Press. (Studies in Historical Theology 3, General Editor: D.C. Steinmetz.) Opitz, P. 1994. Calvins theologische Hermeneutik. Neukirchen: Neukirchener. Jones, S. 1995. Calvin and the rhetoric of piety. Louisville, Kentucky: Westminster John Knox Press. Let us look at a few examples:

A. In a first instance, T.F. Torrance touches on the language issue in the hermeneutics of Calvin:

In part 1 of his The hermeneutics of John Calvin [Edinburgh: Scottish Academic Press, 1988.] Torrance portrays with copious references the background of Calvin's thought. In the second part of this positioning of Calvin in his theological milieu, Torrance describes (1) Calvin's theological and hermeneutical 
respects it exhibits the paradigm shift of the past decade(s), which had been stimulated by the input of Perelman and others on the one hand and P. Ricoeur and others - especially A.C. Thiselton - on the other hand.

The search is therefore not that easy as it has often to be conducted on bypaths. When we now move firstly into the area of hermeneutics proper,

method; (2) outlines the seminal influences from the late medieval period and (3) from the $16^{\text {th }}$ century.

With lucidity Torrance sketches the important methodological contributions by Calvin to theology, which cover more or less the hermeneutical side of the coin.

We can summarise this very briefly.

a. Calvin brought a disciplined method to both his commentaries on scripture and his exposition of key dogmatical issues in his Institutes. This involved a philological and theological interpretation of the Biblical text and constructive thinking in carving out a new approach amidst both contemporaries and interpretation traditions from the past.

b. By combining Biblical exposition (commentaries) and doctrinal reflection (Institutes) Calvin created the norm of a positive theology resting upon its own foundations in the Word of God (p. 61). Torrance reinforced this bold claim with an insightful remark that it was this transfer of a centre or locus of authority from the subject... (p. 71).

c. A corrolary of this principle of objectivity is Calvin's insistence that we should presume nothing about ourselves but everything about God - interpretation should only focus on the glory of God (p. 64).

Accordingly the analogia fidei (faith referring to truth as its source) necessitate the obedientia fidei. In this context humility in relation to the truth of God and obedience in faith constitute the suggestive framework for persuasion by the Word of God of the truth of God. Accordingly Calvin has no interest in presenting novelties.

B. R.C. Gamble on the other side uses 'method' as key to Calvin's hermeneutics. (Gamble, R.C. 1985. 'Brevitas et Facilitas': Toward an understanding of Calvin's Hermeneutic. Westminster Theological Journal 47[1985], pp. 1-17.)

C. Another example, which is less indirect and moreover instructive in several respects, is another study by T. F. Torrance, "Knowledge of God and speech about Him according to John Calvin" (In R.C. Gamble, ed., Calvin's theology, theology proper, eschatology. New York and London: Garland Press, 1992, pp. 86-106). In this article Torrance treats the language issue in tandem with knowledge - one could perhaps generalise and say linguistics coupled to epistemology. Of course this implies a specific view of the human person as well (anthropology). 
let us remind ourselves that we will encounter mostly theological hermeneutics, or Biblical hermeneutics as it is often called, and seldom general philosophical hermeneutics, nor legal hermeneutics or the hermeneutics of communication, finance and the advertising industry and so forth, i.e. one of the special areas of hermeneutics. And in the second instance that the borderline between hermeneutics, methodology and epistemology has become eroded and often intertwined.

\subsection{Conclusive remarks ${ }^{38}$}

I am not in a position to evaluate the total picture, but as far as I can see the major task is now to sift through these contributions for building blocks of Calvin's philosophy of language, testing where each brick would fit into the total picture of the location of language in God's creation. Calvin taught us that the tower of Babel had been built with human pride and an overrated self-esteem as motive. For years the international research community, inspired and led by its energetic and wise secretary, Wilhelm Neuser, had been repairing and refurbishing the Academy of Calvin. In the footsteps of Calvin these scholars have indeed succeeded in opening windows in Geneva to a grateful world of students - with building blocks of bumility. Calvin's view on and use of language is indeed relevant today.

As far as a Christian philosophy of language is concerned, a modest but promising start had been made decades ago with inter alia H.G. Stoker and P.A. Verburg. The main task for the future, so it seems at present, is to follow this up with research on the links between the philosophy of language and aesthetics, rhetoric, ethics and hermeneutics, not forgetting essential recent contributions from the area of the theology of language.

Moreover, the tower of Babel presently has a linguistically relevant message even for Calvin researchers: are we today in the light of technological developments on the right track of balancing the unity and diversity of (academic) languages as far as our communal interest in the inheritance of the Reformation is concerned? How should we approach, for instance, the

38 As co-editor of this Festschrift, who also had the privilege to study philosophy as well as philosophy of language at the feet of the late prof. N.T. (Theo) van der Merwe, I compiled this conlusion from notes and remarks we found on the computer of prof. Van der Merwe, regarding this article. I believe, while taking into account discussions we had on this topic, that this is the best way to show us the direction that prof. Van der Merwe would perhaps have taken in completing this study. 
vexing issue of translation that, for example, George Steiner treated in After Babel (Oxford, 1998) in his own individual way? And what significance should currently be attached to sola scriptura? A slogan in the form of a handy pragmatic tool? Or a power of God for our salvation? Or...? As far as Calvin is concerned, my guess is that he would have opted for sola gratia to show the way to bumilitas.

And perhaps we will also have to add a new trend next to all the others in the development of theories of language through the ages. I have good faith that the Reformed tradition of Christian philosophy, spiritual grandchildren of John Calvin, with its promising start in H.G. Stoker and P.A. Verburg is vibrant enough to help bridge the gap in contemporary 'postmodern' philosophies of language and even 'deconstruct' a few mighty preconceptions as well.

Keywords

Language, Philosophy of

Calvin, John

Genesis

Tower of Babel

Humilitas (humility)

Truth, true and false

Contexts, reference

Modifiers and quantifiers
Trefwoorde

Taal, Filosofie van/ Taalfilosofie

Calvyn, Johannes

Genesis

Toring van Babel

Humilitas (beskeidenheid)

Waarheid, waar en vals

Kontekste, verwysing 